\title{
Rebuilding Social Fabric in Failed States: Examining Transitional Justice in Bosnia
}

\author{
David Hoogenboom \\ Stephanie Vieille \\ The University of Western Ontario \\ Department of Political Science \\ dhoogenb@uwo.ca \\ svieille@uwo.ca
}

Paper prepared for the Annual Meeting of the Canadian Political Science Association, Vancouver, BC, 6 June 2008

Please do not cite without permission from authors 
This paper examines the international community's approach to state-building during the aftermath of warfare. In wake of violent wars and unrest that affects many parts of the world, academics, researchers, and practitioners have noted the increasing involvement of non-state actors and more importantly citizens. This, in turn, results in greater social destruction, where, in most cases, basic levels of societal trust have been destroyed. As a result, the traditional state-building tool-kit including negotiations, building state institutions, running elections, and reconstructing the economy are necessary, but not sufficient for securing peace at the local community level. In response to this, increasing attention has been focused on how societies respond to the need for social reconstruction.

Most recently, the concept of reconciliation in deeply divided societies has attracted attention. Reconciliation is widely considered an important component complementing the conventional war-ending mechanisms; therefore, the process and concept deserve to be investigated. This study demonstrates that the peacebuilding process that has taken place in Bosnia-Herzegovina (hereinafter Bosnia) over the past decade has been unable to foster reconciliation and re-create social trust, two necessary elements for ensuring lasting peace in the aftermath of conflict.

This paper will start with a discussion of the nature of contemporary warfare and the pressing need for a community-centered approach to peacebuilding, which is embodied by the process of reconciliation. In order to do this, we will briefly address the conceptual and theoretical dimensions of the process of reconciliation before focusing on the Bosnian case study. We will argue that substantial efforts have been made by the international community to sustain peace in the region, but these efforts appear to be insufficient, as well as isolated from the communities and individuals that were primarily affected by the conflict. Furthermore, although local efforts to promote social reconstruction have been effective, support for these initiatives has, at times been tenuous and has generally reflected donors' perspectives and interests. This necessitates a recasting of the international community's approach to state-building and a need for more attention to be focused on the basic building blocks of societal peace at the local community level.

\section{On Contemporary Warfare and the Need for Reconciliation}

Interestingly, a number of academics, researchers and practitioners have come to the conclusion that a new form of warfare has emerged. These wars are generally characterized by two aspects: first, modern warfare generally features the involvement of non-state actors and more importantly citizens. Rupesinghe notes the "deliberate targeting of civilians" as a tactic and trend of contemporary conflicts. Such conflict is no longer restricted to battle fields whereby soldiers fight soldiers. More than ever, the protagonists of modern warfare are 'common' citizens and individuals rather than soldiers in uniforms. The fighting takes place within the communities and neighbourhoods themselves. The distinction between combatants and non-combatants is blurred and men, women, children and elders are the first instigators but also casualties of such conflicts. Boyd, for instance, succeeds in bringing to attention the difficulty in distinguishing combatants and non-combatants. ${ }^{2}$ Consequently, he brings to our

\footnotetext{
${ }^{1}$ Kumar Rupesinghe, Civil wars and civil peace: An introduction to conflict resolution (London: Pluto Press, 1998), 51.

${ }^{2}$ Charles Boyd, "Making Peace with the Guilty," Foreign Affairs 74, no.5 (1995): 22-38.
} 
attention the difficulty in addressing post-conflict responsibility, justice and therefore peace. Yet the primary characteristics of war, namely violence and suffering, remain; the means of fighting wars have mutated.

Fletcher and Weinsten, ${ }^{3}$ and Lederach ${ }^{4}$ reveal the increasingly human character of wars, which, in their views, necessitates a more human type of war-ending mechanism, henceforth inter-individual reconciliation. Modern wars are narrowed down to "human suffering at the communal level"5 where citizens and individuals find themselves at the centre of tensions and conflicts. Saunders, similarly, declares that "the human dimension of conflict must become central to peacemaking and building peaceful societies." ${ }^{\prime 6} \mathrm{He}$ alludes to the importance of reconciliation among citizens of a war-ridden country when he adds that "only governments can write peace treaties, but only human beings, citizens outside of the government can transform conflictual relationships [...] into peaceful relationships."7 From this line of thought results the belief that a more human type of war necessitates more individual/citizen centred mechanisms of conflict resolution.

The second characteristic of modern warfare is identified by both Lederach and Busumtwi-Sam as a "protracted" 8 or "intractable" dimension. The authors in fact refer to the embedded-ness of certain conflicts within the history and even structure of a given society. The physical violence and fighting are only the visible tip of the iceberg which emerges from a deep malaise within the society. Such conflicts are characterized by long cycles of animosity, anger and distrust that have sometimes even been institutionalized ${ }^{10}$ by years of bitterness and latent oppression. Whether governments themselves were at the origin of such animosity or not, is no longer central to the conflict and its solution, which lies in the complete reorganization of the social order and apparatus. Assefa adds an interesting note to the necessity of an alternative type of conflict resolution when he posits that "traditional conflict management strategies are not adequate to deal with the kinds of contemporary conflict raging in many parts of the world." ${ }^{11}$ When talking about "traditional conflict management," Assefa refers to processes such as negotiation, arbitration and other state-centred actions, which he sees as inefficient in light of modern warfare and for the reasons aforementioned. It therefore stems from this analysis that the radically different nature of modern warfare brings forth new challenges to peacebuilding, challenges which cannot solely be dealt with at the state level, but demand increasing citizen participation.

\footnotetext{
${ }^{3}$ Laurel E. Fletcher and Harvey M. Weinstein , "Violence and Social Repair: Rethinking the Contribution of Justice to Reconciliation"Human Rights Quarterly 24, no.3 (2002): 573-639.

${ }^{4}$ John Paul Lederach, Building Peace: Sustainable Reconciliation in Divided Societies (Washington: United States Institute of Peace Press, 1997).

${ }^{5}$ Fletcher and Weinsten, Violence, 575.

${ }^{6}$ Harold Saunders, A Public Peace Process: Sustained Dialogue to Transform Racial and Ethnic Conflict

(New York: Palgrave, 1999), xvii.

${ }^{7}$ Ibid., Xvii.

${ }^{8}$ James Busumtwi-Sam, "Sustainable Peace and Development in Africa," Studies in Comparative International Development 37, no. 3 (2002): 93.

${ }^{9}$ Lederach, Building, 14.

${ }^{10}$ Busumtwi-Sam, Sustainable, 93.

${ }^{11}$ Hiskiaz Assefa, "The Meaning of Reconciliation People Building Peace," European Platform for Conflict Prevention and Transformation. http://www.gppac.net/documents/pbp/part1/2_reconc.htm. (accessed April 22, 2006)
} 
From this understanding follows the statement that modern warfare challenges well-established peacemaking and peacebuilding strategies. If we are indeed witnessing the emergence of a radically different type of war, should we not attempt to put forward adequate and different war-ending mechanisms? The writings of academics and practitioners of conflict resolution all reveal a stringent need to rethink traditionally understood mechanisms of conflict management and directly or indirectly refer to a process of reconciliation; a process whose nature and aspects have so far gathered little consensus.

\section{Reconciliation: a concept}

An initial step towards understanding reconciliation is to recognize the paradox emerging from the literature on conflict resolution. Indeed, while the concept of reconciliation is recurrent and present in most, if not all, the books and articles reviewed, it succeeds in keeping its elusive character and lacks "complete theorizing." 12

Reconciliation is widely understood and described as a process involving different parties to a conflict or dispute. It is depicted as "pro-active" 13 and "dynamic" 14 in that it requires full participation rather than passive acceptance and observation of the process. Assefa explains that reconciliation fundamentally differs from all other types of conflict resolution mechanisms in that it requires the highest degree of "mutual participation."15 The participation and commitment of disputing parties to maximize peacebuilding is generally weaker in other more conventional types of conflict resolution such as negotiation or arbitration. Saunders puts forward the most interesting account of reconciliation or what he calls a "public peace processes," which he identifies as a dialogue. ${ }^{16}$ Dialogue as an integral part of the process of reconciliation is described as a "process of genuine interaction" 17 whereby parties listen and analyse the past in order to agree on the present and future. Dialogue is what makes reconciliation an active and forceful process. More importantly, the process of reconciliation between past enemies is seen as means to link both past and present, by acknowledging past wrongdoings and looking forward to peaceful coexistence and possibly the future reintroduction of past offenders into the community, as noted by Faulkner in his case study of Sierra Leone. ${ }^{18}$

Reconciliation is no fast business. Indeed, it is portrayed as a lengthy process that involves several stages, although their number and nature are unclear. Interpretations vary. Dwyer, for instance, mentions three stages: first, the initial investigation of events; second, truth telling; and, third, acknowledgement of past wrongs. ${ }^{19}$ Saunders' interpretation differs in that he puts forth what he calls a five stage "public peace process, $" 20$ encompassing the initial planning to the final reconstruction of social trust,

\footnotetext{
${ }^{12}$ Donna Pankhurst, "Issues of Justice and Reconciliation in Complex Political Emergencies:

Conceptualising Reconciliation, Justice and Peace," Third World Quarterly 20, no.1 (1999): 252.

13 Assefa, Meaning.

${ }^{14}$ Saunders, Public, 26.

${ }_{15}$ Assefa, Meaning.

${ }^{16}$ Saunders, Public, 82.

${ }^{17}$ Ibid., 82.

${ }^{18}$ Frank Faulkner, "Kindergarten Killers: Morality, Murder and the Child Soldier Problem" Third World Quarterly 22, no.4 (2001): 491-504.

${ }^{19}$ Susan Dwyer, "Reconciliation for Realists" Ethics and International Affairs 13 (1999): 7.

${ }^{20}$ Saunders, Public, 97.
} 
while Rigby ${ }^{21}$ articulates a four stages process starting from the securitisation of peace and ending with apology.

\section{Reconciliation: a process}

However, it is difficult to define precisely what the process of reconciliation entails. The literature provides no clear definitions, and there is, as yet, no consensus as to its meaning. Truth, justice, apology, forgiveness and accountability are all recurrent themes, yet they lack thorough conceptual development and prove to be at the centre of much animated discussion. Indeed, while truth-telling seems to receive unanimous support, the concept and role of apologies and forgiveness, for instance, lie at the centre of an important debate regarding whether they are necessary or even possible in case of mass violation of human rights. A brief reference to the literature will confirm this statement. Dwyer, for instance, suggests that "reconciliation and forgiveness are conceptually independent." 22 Simply put, reconciliation does not require forgiveness in order to be successful. Such a notion stems from an understanding of reconciliation as a public process, in contrast with the more personal and psychological exercise that is forgiving. Dwyer does not reject the possibility of forgiveness within the process of reconciliation, but, rather, maintains that both are conceptually independent and while they may occur simultaneously, they do not rely on each other. Rigby's ${ }^{23}$ and Jeong's ${ }^{24}$ versions radically differ from that of Dwyer. Both conceive the act of forgiving and apology as a step towards reconciliation. Reconciliation is, in part, forgiving and apologising (on both sides) for past actions. Interestingly, no consensus or middle ground is ever reached in the literature on the subject.

However difficult the task of defining reconciliation appears to be, there seems to be a consensus on the purpose of reconciliation. While the bulk of the literature reviewed cannot agree on one single definition of reconciliation and on what the process entails, all concur with the notion that the process and politics of reconciliation are best suited to address root causes and prevent further conflict. Hizkias describes the process of reconciliation as a means of conflict prevention and transformation. He adds that reconciliation is most likely to "allow future positive and harmonious relationships between opposing parties." 25 Dwyer also sees in reconciliation "an end to antagonism" and the beginning of "healing and repair of relationships," ${ }^{26}$ while Jeong argues that reconciliation aims at rebuilding "social trust." 27 In any case, justice brought about by reconciliation is confirmed as the best way to alleviate and reduce both victimization and scapegoating: two particularly dangerous elements in protracted conflicts. The process of reconciliation represents a radically different approach to peacebuilding because it aims to establish a restorative rather than retributive type of justice. Assefa describes justice as

\footnotetext{
21 Andrew Rigby, Justice and Reconciliation: After the Violence (Boulder: Lynne Rienner Publishers, 2001), 186.

${ }^{22}$ Dwyer, Reconciliation, 7.

${ }^{23}$ Rigby, Justice, 187.

${ }^{24}$ Ho-Won Jeong, Peacebuilding in post conflict societies: strategy \& processes (Boulder: Lynne Rienner Publisher, 2005), 156.

${ }^{25}$ Assefa, Meaning.

${ }^{26}$ Dwyer, Reconciliation, 2.

${ }^{27}$ Jeong, Peacebuilding, 156.
} 
"the core of reconciliation" 28 while Rigby quite forcefully adds that reconciliation that does not bring about justice is a "failed reconciliation." 29

According to Govier, reconciliation must be conceived of as existing on a broad spectrum. On one end, reconciliation is given a thick conception, full of "emotional richness" and extends the focus to include community-level approaches. ${ }^{30}$ On the other end, or the thin conception, reconciliation is conceived of as focused on institutional and behavioural factors, void of emotions. ${ }^{31}$ Govier's spectrum of possibilities includes the following:

1. Reconciliation is unity.

2. Reconciliation is harmony

3. Reconciliation is healing, of individuals and relationships.

4. Reconciliation is forgiveness, following on remorse and apology.

5. Reconciliation is the building of decent relationships.

6. Reconciliation is truth acknowledged

7. Reconciliation is restorative justice, involving remorse on the part of perpetrators and reparations for victims.

8. Reconciliation is retributive justice, requiring the punishment of offenders.

9. Reconciliation is democratization, requiring the development of legal, electoral and parliamentary institutions.

10. Reconciliation means that people have stopped using physical violence against each other. ${ }^{32}$

The international community has focused much of its attention on the thin conceptions of reconciliation including ending physical violence, democratization, and retributive justice. This paper concentrates on thick reconciliation, which necessitates a focus on community and the reconstruction of social trust at that level. Particularly, we are interested in the role reconciliation can play at the community level and how this approach to peacebuilding, taken by the international community, affect the restoration of relationships at the local level.

Govier outlines an important connection between trust, relationships, and reconciliation. In order to engender sustainable societal peace, former enemies must be able to forge new relationships built on trust. By building new relationships, former enemies can overcome past antagonism. If there is a genuine process of reconciliation, those engaged can begin to overcome feelings of fear and suspicion. Former adversarial relations can be transformed to "more positive, constructive relationships" between citizens with a genuine stake in a collective future. ${ }^{33}$ Similarly, Saunders asserts that, "only governments can write peace treaties, but only human beings can transform conflictual relationships between people into peaceful relationships." "34 By recognizing this human dimension, a transformation in the study and practice of peacebuilding, and conflict management and resolution is needed. And, as long as this dimension is

\footnotetext{
${ }^{28}$ Assefa, Meaning.

${ }^{29}$ Assefa, Meaning.

${ }^{30}$ Trudy Govier, Taking Wrongs Seriously: Acknowledgement, Reconciliation, and the Politics of

Sustainable Peace (Amherst: Humanity Books, 2006), 13.

${ }^{31}$ Ibid.

32 Ibid.

${ }^{33}$ Govier, Taking Wrongs Seriously, 13.

${ }^{34}$ Saunders, Public, xvii.
} 
relegated to the afterthoughts of peacebuilding, after formal mediations, negotiations economic development, building state-institutions and running elections, institutionalbuilding (states, governments and formal organizations) a transformation must take place in the way we approach state-building. While there has clearly been a recognition of this human dimension, it has not translated into a "full part of the operational picture.",35

In review, we suggest that contemporary conflict, characterized by long cycles of animosity, anger, and distrust has resulted in a greater human dimension to conflict. As a consequence, traditional conflict management techniques (characterized by the Govier's thin conception of reconciliation), while continue to be necessary, are not sufficient in dealing with the resulting levels of social upheaval and the destruction of the basic social fabric. In response to this, we suggest that the international community must recognize the need for thicker forms of reconciliation for sustainable peace.

\section{Case Study: Bosnia}

The Yugoslavian wars broke out in June, 1991, following Slovenia and Croatia's declaration of independence from the Yugoslav federation. While hostilities between Slovenian nationalists and the Yugoslav National Army (JNA) were short lived, fighting between the Croatian nationalist forces and ethnic Serb paramilitary units within Croatia (supported by the JNA) lasted through to the latter part of 1991. In March 1992, a referendum regarding independence from Yugoslavia was held in Bosnia. While the Bosniak and Croat residents were in favour of independence, the Serb population was strongly against leaving the Yugoslav federation and refused to participate in the referendum. Hostilities broke out following the overwhelming support for independence in Bosnia. ${ }^{36}$ The Bosnian war lasted over three and a half years. During this time, there were approximately 230,000 casualties, and 2.3 million displaced persons. ${ }^{37}$ The American brokered peace talks were successful in bringing an end to the armed conflict between the Bosniaks, Croats, and Serbs with the signing of the General Framework Agreement for Peace in Bosnia and Herzegovina (the Dayton Accord). The Dayton Accord contained eleven annexes, including the new Constitution, and outlined the roles and responsibilities of the Bosnians and the international agencies charged with its implementation.

Thirteen years after the war, Bosnia remains under the auspices of the Peace Implementation Council (PIC) headed by the Office of the High Representative and European Union Special Representative (OHR). ${ }^{38}$ The human rights situation on the ground, however, has remained problematic in large parts of Bosnia. While there have been numerous advancements towards a democratic state, several obstacles have severely limited the growth of liberal democratic traditions.

\footnotetext{
35 Ibid.

${ }^{36}$ Roland Paris, At War's End: Building Peace after Civil Conflict, (Cambridge: Cambridge University Press, 2004), 98.

${ }^{37}$ Marcus Cox, "Building Democracy from the Outside: The Dayton Agreement in Bosnia and Herzegovina," in Can Democracy Be Designed: The Politics of Institutional Choice in Conflict-torn Societies, ed. Sunil Bastian and Robin Luckham. (London: Zed Books, 2003), 256.

${ }^{38}$ The Peace Implementation Council comprises 55 countries and agencies that support the peace process in Bosnia. The OHR is responsible for overseeing implementation of civilian aspects of the Dayton accord.
} 
The ethnic lines that divided Bosnia during the war were eventually reproduced in post-war politics. ${ }^{39}$ The multi-ethnic Bosnia emerged from the war as a state with two distinct entities: Republika Srpska (RS, Serb-dominated territory) and the Federation of Bosnia and Herzegovina $(\mathrm{FBiH}){ }^{40}$ The Federation was further divided into cantons that had clearly defined ethnic (Bosniak or Croat) majorities. ${ }^{41}$ According to Guzina, Bosnia emerged as a state territorially fragmented according to the principle of ethnic homogenization, which exacerbated the legacy of ethnic cleansing. ${ }^{42}$ While a great deal of effort has been focused on the successful implementation of the right to return for refugees, the reality on the ground suggests that most returnees were avoiding areas where they did not constitute the ethnic majority. Thus, remixing the ethnic map of Bosnia remains an elusive goal of the international community. ${ }^{43}$

\section{Reconciliation through Liberal Democratic Institutions}

The goal of the Dayton Accord was to transform Bosnia to a liberal democratic state on the belief that this would safeguard the country from future violence. ${ }^{44}$ This goal is immediately stated in the preamble of the country's new Constitution located in Annex 4 of the Dayton Accord. The Constitution asserts its dedication to "peace, justice, tolerance, and reconciliation" and that it is "convinced that democratic governmental institutions and fair procedures best produce peaceful relations within a pluralist society." 45 Guzina suggests that the drafters of the Dayton Peace Agreement believed that democratic governance needed to be "fine-tuned to manage ethnic and cultural diversity in conflict-torn Bosnia." 46 The drafters recognized that ethnic identities would remain salient in post-Dayton Bosnia and, therefore, needed to be addressed in the Constitution. As a result, the Dayton Accord incorporated several techniques to manage ethnic conflict. These included: "federalisation and internal partition of Bosnian territory; the formal recognition that the Bosnian state belongs to three constitutive peoples on the principle of political equality (Serbs, Croats, and Bosniaks); the implementation of the highest possible international human rights standards (Annex 6); and the right to return home of refugees and internally displaced persons (Annex 7)."

Holding this decentralized and multi-ethnic state together was achieved through the implementation of power-sharing mechanisms. By institutionalizing ethnic identities, it was believed that these power-sharing mechanisms could provide the government with significant legitimacy immediately following the war. Lijphart contends that in societies with salient cleavages, the interests and demands of groups can only be contained through

\footnotetext{
${ }^{39}$ Florian Bieber, Post-War Bosnia: Ethnicity, Inequality and Public Sector Governance (New York: Palgrave Macmillan, 2006), 41.

${ }^{40}$ Ulrich Schneckener, "Making Power-sharing Work: Lessons from Successes and Failures in Ethnic Conflict Regulation," Journal of Peace Research 39, no. 2 (2002): 209.

${ }^{41}$ Dejan Guzina, "How Multiethnic is Democracy in the Balkans: The Case of Bosnia," Paper presented at the annual meeting of the International Studies Association, Hilton Hawaiian Village, Honolulu, Hawaii, March 5, 2005, available from http://www.allacademic.com/meta/p70760_index.html (accessed April 1, 2008), 5 .

42 Ibid.

${ }^{43}$ Guzina, Dejan. "Dilemmas of Nation-building and Citizenship in Dayton Bosnia," National Identities 9 , no. 3 (2007): 229.

${ }^{44}$ Paris, At War's End, 99.

${ }^{45}$ General Framework Agreement for Peace in Bosnia and Herzegovina (1995), Annex 4.

${ }^{46}$ Guzina, Dilemmas of Nation-building, 222.

${ }^{47}$ Guzina, Dilemmas of Nation-building, 222
} 
the implementation of power-sharing techniques. ${ }^{48}$ The Theory of Consociationalism suggests that the key to designing effective institutions is not to eliminate ethnic politics. Instead, preserving the interests and identities of individuals in societies with deep communal cleavages needs to be recognized through group rights. This strategy should accept the presence of ethnicity in politics and attempt to build bridges between the groups. Consequently, the Constitution institutionalized ethnicity with the introduction of a tri-ethnic rotating presidency, ethnic-based federalism (based on the Republika Srpska, RS, and the Bosniak and Croat Federation, FBiH), mutual veto, and ethnic proportional representation in the bureaucracy. While the Dayton Accord clearly intended to promote and support interethnic cooperation, it consequently reinforced divisions among the three constituent nations in Bosnia through the implementation of such powersharing mechanisms.

In the first few years following the war, state institutions were largely nonfunctional as much of the country's political power rested in the entities (FBiH and RS), rather than the central state. As a result, there was minimal investment in the state by the Croat and Serb nationalist parties. Instead, they opted to work within the entities and cantons, which proved constitutionally stronger.

Power-sharing democracies have been successful when built on a significant level of societal trust. But Bieber argues that there is a considerable lack of mutual trust in Bosnia. ${ }^{50}$ While this can be attributed to the recent history of the region, it appears that there are other factors that have limited the growth of a stable social infrastructure. Because of the early support of the national parties and the subsequent political deadlock, the Peace Implementation Council (the group of nations that oversaw the peace agreement in Bosnia) increased the powers of the OHR. Consequently, the OHR was given power over institutional reform, drafting and passing of legislation, and the dismissal of elected officials. ${ }^{51}$

Scholars contend that "Bosnian society is dramatically lacking a sense of belonging to its own country." 52 Furthermore, the international community has remained an intrusive presence in Bosnia. Knaus and Cox believe that the "system of illiberal democracy under international supervision has now become the most serious constraint on the development of an effective state." 53 Bosnian citizens view the international agencies, instead of their own politicians, as the "real locus of power." 54 Out of concern for potential backlash, Bosnian politicians allow the international agencies to make the unpopular decisions. Accordingly, "this creates a self-reinforcing dynamic of low public

\footnotetext{
${ }^{48}$ Arend Lijphart, "Constitutional Design for Divided Societies," Journal of Democracy 15, no. 2, (2004): 96.

${ }^{49}$ Florian Bieber, "Institutionalizing Ethnicity in the Western Balkans. Managing Change in Deeply Divided Societies." ECMI Working Paper, No. 19 (2004), 4.

${ }^{50}$ Florian Bieber, "The Challenge of Democracy in Divided Societies: Lessons from Bosnia - Challenges for Kosovo," in Reconstructing Multi-ethnic Societies: The Case of Bosnia-Herzegovina, eds. Dzemal Sokolovic and Florian Bieber (Aldershot: Ashgate, 2001), 115.

${ }^{51}$ Guzina, Dilemmas of Nation-building, 224.

${ }^{52}$ Zoran Pajic, "Statehood at a Crossroads," Tol.cz, February 10, 2006, http://www.tol.cz/look/TOL/article .tpl ?IdLanguage $=1 \&$ IdPublication $=4 \&$ NrIssue $=153 \& \mathrm{NrSecti}$ on $=2 \&$ NrArticle $=15812 \&$ search $=$ search $\& S e$ archKeywords $=$ Pajic\&SearchMode $=$ on $\&$ SearchLevel $=0$ (accessed December 1, 2007).

${ }^{53}$ Gerald Knaus and Marcus Cox, "Bosnia and Herzegovina: Europeanization by decree?" in The western Balkans moving on (Chaliot Papers No. 70), ed. Judy Batt (Paris : Institute for Security Studies, 2004), 55.

${ }^{54}$ Knaus and Cox, Bosnia and Herzegovina, 59.
} 
expectations and low performance, and contributes to a distaste for politics in general."55 The suspension of politics in Bosnia has removed the centres of negotiation and bargaining that create trust over time. Loza argues that the Bosnian society continues to be dominated by ethnic sentiments, and that "very few journalists in Sarajevo deviate from the official nationalist narrative. When it comes to the manufacturing of hysterical political ideas, priests, writers, and academics lead the way in today's Sarajevo as they did in Belgrade in the 1980s."

Further, the Dayton Accord provided little direction for how to proceed with reconciliation beyond a state-centred peace-agreement and Constitution. The war in Bosnia was characterized by terrible and widespread atrocities, in which lasting peace and reconciliation was impossible without some form of accountability for the ordering and commission of such crimes. ${ }^{57}$ In response to this, the International Criminal Tribunal for the Former Yugoslavia (ICTY) was established in 1993 to deliberate over cases of crimes against humanity. Consequently, the ICTY has served as the principal vehicle for justice in Post-Dayton Bosnia, and has been the primary mechanism for social reconciliation. The mechanisms upon which the international community has relied upon in Bosnia remain within Govier's thin conception of reconciliation and are not sufficient for the rebuilding of Bosnia's social fabric.

\section{Reconciliation through Retributive Justice}

Kerr suggests that justice, through courts like the ICTY, can contribute to peace by attributing individual criminal accountability. Therefore, in the aftermath of violence, instead of viewing all groups as former aggressors, the individualization of guilt explicitly identifies those responsible for the atrocities. ${ }^{58}$ In conflicts characterized by widespread atrocities, it appears that lasting peace and reconciliation require retributive justice. While reconciliation may be a lofty goal for prosecution, it seems plausible that "in the absence of some form of institutionally provided justice, people will presumably increasingly tend toward less peaceful forms of political action to achieve their aims."

Akhavan argues that there is evidence which suggests that criminal tribunals such as the ICTY and its equivalent in Rwanda "have significantly contributed to peacebuilding in postwar societies, as well as to introducing criminal accountability into the culture of international relations." 60 These institutions contribute to peace by marginalizing nationalist political leaders and by discouraging vengeance by victim groups. Teitel suggests that a court such as the ICTY "symbolizes the possibility of change in the region. It offers the potential of moving from persecutory violence to the

\footnotetext{
${ }^{55}$ Knaus and Cox, Bosnia and Herzegovina 59.

56 Tihomir Loza, "Shades of Yugoslavia," Tol.cz, September 25, 2007, http://www.tol.cz/loo k/TOL /article .tpl?IdLanguage $=1 \&$ IdPublication $=4 \& N r$ Article $=19016 \&$ NrIssue $=237 \& N r S e c t i o n=2$

(accessed 27 November 2007).

${ }^{57}$ Rachel Kerr, "The Road from Dayton to Brussels? The International Criminal Tribunal for the Former Yugoslavia and the Politics of War Crimes in Bosnia," European Security 14, no. 3 (2005): 322.

${ }^{58}$ Kerr, The Road from Dayton, 322-3.

${ }^{59}$ James Meernik, "Justice and Peace? How the International Criminal Tribunal Affects Societal Peace in Bosnia," Journal of Peace Research 42, no. 3 (2005): 272.

${ }^{60}$ Payam Akhavan, "Beyond Impunity: Can International Criminal Justice Prevent Future Atrocities?"

American Journal of International Law 95, no. 1 (2001): 9.
} 
rule of law. Within the rule of law, past wrongs cannot serve to justify the ongoing perpetration of massacres and atrocities." 61

Several observers are not as convinced of the utility of international justice for peace and reconciliation. Hesse and Post argue that "the international community can itself enforce legal requirements and punish crimes against humanity, as it did at Nuremburg, and it may thereby produce many highly beneficial results, but such prosecution cannot create the rule of law within a nation. Prosecutions in The Hague[Netherlands] will not by themselves establish the rule of law in Bosnia. That can only be accomplished by Bosnians acting through Bosnian institutions." 62 The imposition of justice from above is the cause of great scepticism for Hesse and Post. Snyder and Vinjamuri echo these concerns, claiming that little evidence exists from recent cases that support the claim that international trials deter future atrocities, consolidate the rule of law or democracy, or provide a solid foundation for peace. ${ }^{63}$

There was a great deal of pressure on the United Nations (UN) to formulate a response to punish those who committed mass atrocities and genocide during the Yugoslav wars. To address these concerns, the UN established the ICTY in 1993. The parameters of the court's jurisdiction were set to prosecute those individuals who committed crimes against humanity, war crimes, and genocide during the Yugoslav wars (Serb-Croat war, Serb-Bosnia war and the Kosovo war). To prosecute these individuals, an international, independent prosecutor was given the responsibility of indicting, arresting, and bringing to trial culpable leaders. The ICTY began to indict criminals in The Hague, Netherlands, in 1995. By 2002, over 90 individuals had been indicted for war crimes and several had already been tried. ${ }^{64}$

The UN Security Council's establishment of the ICTY was viewed as a precedent-setting decision. According to Neier, "it was the first time in its forty-eightyears history that it tried to bring anyone to justice for committing human rights abuses." 65 In other words, the UN was finally putting its muscle and moral authority where it counted (or hoped to count). ${ }^{66}$ Fletcher and Weinstein contend that "diplomats, the media, and supporters of the court sought to expand its legal mandate beyond the goal of prosecuting alleged perpetrators of war crimes. They wanted the court to achieve a larger, more ill-defined, and unrealistic objective of promoting reconciliation among warring groups." ${ }^{\prime 67}$ Initially, the architects of the Tribunal hoped that the court would contribute to the promotion of reconciliation through the creation of an irrefutable

\footnotetext{
${ }^{61}$ Ruti Teitel, "Bringing the Messiah Through the Law," in Human Rights in Political Transitions: Gettysburg to Bosnia, ed. Carla Hesse and Robert Post (New York: Zone Books, 1999), 188.

${ }^{62}$ Carla Hesse and Robert Post, "Introduction," in Human Rights in Political Transitions: Gettysburg to Bosnia, ed. Carla Hesse and Robert Post (New York: Zone Books, 1999), 18.

${ }^{63}$ Jack Snyder and Leslie Vinjamuri, "Trials and Errors: Principle and Pragmatism in Strategies of International Justice,” International Security 28, no. 3 (2003/4): 20.

${ }^{64}$ Howard Ball, War Crimes and Justice: A Reference Handbook (Santa Barbara: ABC- CLIO, Inc., 2002), 25.

${ }^{65}$ Aryeh Neier, War Crimes: Brutality, Genocide, Terror, and the Struggle for Justice (New York: Times Books, 1998), 21.

${ }^{66}$ Ibid.

${ }^{67}$ Laurel E. Fletcher and Harvey M. Weinstein, "A world unto itself? The application of international justice in the Former Yugoslavia," in My Neighbour, My Enemy: Justice and Community in the Aftermath of Mass Atrocity, eds. Eric Stover and Harvey M. Weinstein (Cambridge: Cambridge University Press, 2004), 30.
} 
historical record of the war in order to prevent a hijacking of history by revisionists. ${ }^{68}$ These goals were not unwarranted. Security Council records suggest that the goals of the Court included the punishment of those guilty of war crimes in order to bring justice for victims; to provide a truth about the atrocities of the war; and to deter future war criminals. Overall, the Security Council hoped that the ICTY would contribute to reconciliation in the region. ${ }^{69}$

In the end, the UN Resolution that created the ICTY "[made] no mention of the need to build foundations for social reconstruction in the former Yugoslavia, including consolidation of a national, shared history of the war; the creation of domestic legal institutions that promote and respect strict adherence to the protection of human rights; and democratic institutions capable of guaranteeing individual rights and freedom."70 Further, Drumbl suggests that while reconciliation and peace were identified by the Security Council as objectives of the ICTY, the judges did not give them much consideration. $^{71}$ The ICTY initially had few formal mechanisms that directly linked the Bosnian judicial system and other legal and social institutions in the country to the tribunal. Therefore, few connections were made between state-building in Bosnia and the application of international law in The Hague. ${ }^{72}$ The lack of connections, coupled with the fact that the ICTY had primary jurisdiction over war crimes prosecutions, meant that the Bosnian legal system benefited little from the international court. Consequently, many legal professionals in Bosnia felt marginalized by the court. ${ }^{73}$ It is evident, then, that this remoteness and subsequent insulation from the region created a disconnect between the court proceedings and events on the ground. ${ }^{74}$ This disconnection between the court and the society/community-level resulted in fewer opportunities for thicker forms of reconciliation. The court's questionable effectiveness in promoting reconciliation was evident in the local perceptions of it.

Perceptions of the Court

A study found that almost all Bosnian Serb and Croat participants expressed concern that the ICTY was biased and incapable of providing fair trials. ${ }^{75}$ The international community's initial regulations devised for the ICTY specifically excluded nationals from the war-torn states (in this case, Bosnia) from holding legal positions at the court. This decision was made to avoid accusations of bias, but the exclusion fostered feelings on the part of some groups of being abused by the international legal community. It also cultivated feelings among Bosnian Croats and Bosnian Serbs that "the work of the tribunal did not reflect their concerns and therefore they could not claim any ownership in the judicial process."76 Further, in a series of interviews with legal professionals in Bosnia, opinions of the Court were largely a function of ethnic identity: Bosniaks "adhered most closely to the view that the ICTY would promote social reconstruction.

\footnotetext{
68 Ibid., 37.

${ }^{69}$ Ibid., 36-37.

${ }^{70}$ Fletcher and Weinstein, A world unto itself, 37.

${ }^{71}$ Mark Drumbl, Atrocity, Punishment, and International Law, (New York: Cambridge University Press, 2007), 62.

${ }^{72}$ Fletcher and Weinstein, $A$ world unto itself, 30.

${ }^{73}$ Snyder and Vinjamuri, Trials and Errors, 22.

74 Teitel, Bringing the Messiah, 189.

${ }^{75}$ Fletcher and Weinstein, A world unto itself, 33.

${ }^{76}$ Fletcher and Weinstein, A world unto itself, 32.
} 
They saw the tribunal as an important vehicle for acknowledging the status of Bosniaks as victims of Bosnian Serb and Bosnian Croat aggression."77 Conversely, Bosnian Serbs held mixed feelings toward the Court and its relevance in rebuilding their country. They were not convinced with the efficacy of the court in contributing to the social reconstruction of the state. One Bosnian Serb judge stated: "[w]hen someone wants to forgive somebody, he'll do it without a court." 78

Given the limited connections between the ICTY and Bosnia, Fletcher and Weinstein argue that the trials did not succeed in establishing an irrefutable record. Instead each national group reinterpreted the facts and aligned them with their own ethnic identities. $^{79}$ The trials could not preclude the culture of denial in many parts of the state. Snyder and Vinjamuri claim that once ethnicity has been polarized by intergroup violence, "it generally takes a decisive change in strategic circumstances and political institutions, not just the invocation of legal norms, to convince people to think in terms of individual rather than group responsibility." 80 As a result, instead of individualizing guilt as this liberal response to atrocities supposedly achieves, "many Serbs complained that the tribunal unfairly target[ed] Serbs, while many Croats have argued that their group [was] unfairly singled out." 81 Furthermore, some observers suggest that the establishment of a historical record was undermined by the judicial system of pleabargains. In the case of former Republika Srpska President, Biljana Pavsic, a great deal of backlash emerged after she plea-bargained for lesser charges of persecution instead of genocide. Her sentence of 11 years' imprisonment in February 2003 was controversial, despite her feelings of remorse. While it put on record the accountability of the highest level of Bosnian Serb wartime leadership, it was argued that the plea-bargaining did not allow for sufficient retribution and that dropping charges as serious as these undermined the overall record. ${ }^{82}$

Drumbl argues that there is an inherent democratic deficit in international criminal tribunals; "instead of building accountability and restoration from the bottom-up through integration of indigenous laws, customs, personalities, politics, and practices, international criminal law interventions drop from the top-down." ${ }^{83}$ This is evident by the primacy given to the ICTY over Bosnia's domestic courts. The ICTY judges could not be held accountable by the Bosnian population. Outreach programs were initiated, but their effects have been modest and are largely tools for disseminating information about the tribunals. ${ }^{84}$

Reconciliation at the Local Community Level

The Western conception of civil society is that of a space that exists between the household and the state where people develop relationships and interact independently from state institutions. According to Taylor, "it includes those dimensions of social life

\footnotetext{
${ }^{77}$ Ibid., 38.

78 Ibid., 38.

${ }^{79}$ Ibid., 44.

${ }^{80}$ Snyder and Vinjamuri, Trials and Errors, 21.

81 Ibid.

${ }^{82}$ Kerr, The Road from Dayton, 323-324.

${ }^{83}$ Drumbl, Atrocity, Punishment, and International Law, 134.

${ }^{84}$ Drumbl, Atrocity, Punishment, and International Law, 134.
} 
which cannot be confounded with, or swallowed up, in the state." ${ }^{85}$ The normative underpinning of the advancement of civil society is based on the belief that a vibrant civil society can act as an important check on the powers of government. Civil society can help foster political pluralism and create channels for citizens to articulate their views and demands to the state. Consequently, these channels encourage tolerance, trust, and cooperation among its citizens and have the potential to foster new relationships in society. ${ }^{86}$

Local NGOs play an important role in shaping policy by applying pressure on governments and providing technical support to policy makers. An active civil society can often play a valuable role by disciplining the state and ensuring that citizen interests are taken seriously. ${ }^{87}$ NGOs comprise just one element of civil society along side citizens' action groups, the independent media, and an informed public. However, according to Sejfija, NGOs are the dominant component in Bosnian civil society. From 1992 to 2001, 8,000 NGOs committed to humanitarian issues were officially registered. Roughly 30,000 projects were initiated addressing social issues including democratization, human rights, women's rights, youth work, intercultural communication, political education, the environment, and conflict management. ${ }^{88}$

Certainly, several local NGOs oriented towards societal needs have achieved positive results, thus contributing to the peacebuilding processes and beginning the re-building of the country's social fabric. For example, Nenad Vukosavljevic, a peace activist from Belgrade started the Centre for Nonviolent Action (CNA) with considerable support from the Berghof Research Centre, to offer training in nonviolent conflict transformation and grew to a team of active young people from Bosnia, Croatia and Serbia-Montenegro. The activities of the CNA include training for conflict transformation and providing opportunities to discuss real issues of violence, government, and empowerment. ${ }^{89}$ More recently, they have offered activities throughout the region that promote a self-critical process of dealing with the past. These workshops help participants assume responsibility for their actions and lives. ${ }^{90}$ According to CNA, Bosnian society must overcome the victimization, take responsibility for the past and reject violence as a means to resolve conflict. ${ }^{91}$ Their approach, then, seeks to raise public awareness that the past must be addressed and no longer ignored by society. ${ }^{92}$ The group has been successful in creating cross-

\footnotetext{
${ }^{85}$ Charles Taylor, "Civil Society in the Western Tradition," in The Notion of Tolerance and Human Rights eds. Ethel Groffier and Michel Paradis (Ottawa: Carleton University Press, 1991), 117.

${ }^{86}$ Patrice C. McMahon, "Rebuilding Bosnia: A Model to Emulate or to Avoid?" Political Science Quarterly 119, no. 4, (2004/2005): 576.

${ }^{87}$ Sarah E. Mendelson and John K. Glenn, "Transnational Networks and NGOs in Postcommunist Societies," in The Power and Limits of NGOs, eds. Sarah E. Mendelson and John K. Glenn (New York: Columbia University Press, 2002), 6 and; Thomas Carothers and William Barndt, "Civil Society," Foreign Policy no, 117, (Winter 1999/2000): 19-20.

${ }^{88}$ Ismet Sejfija, "From the 'Civil Sector' to Civil Society?" in Peacebuilding and Civil Society in BosniaHerzegovina: Ten Years after Dayton ed. Martina Fischer (Munster: Lit-Verlag, 2006), 125.

${ }^{89}$ Martina Fischer, Confronting the Past, 388.

${ }^{90}$ Ibid.

${ }^{91}$ Martina Fischer, Confronting the Past, 391.

${ }^{92}$ Ibid., 392.
} 
border network of experts from the education sector, the media, and the NGO community. ${ }^{93}$

In her research, Pickering found that in Bosnia, the civic associations that are best positioned to positively influence societal conditions are those groups that are "responsive to local needs" and not necessarily oriented towards ethnically defined interests. ${ }^{94}$ For example, youth groups focused on "concrete tasks" and not necessarily on interethnic relations, generally strengthened interethnic cooperation among the participants as a "by-product" when working together. ${ }^{95}$ Further, several women's groups with an ethnically mixed membership have positively impacted the lives of women returning home after the conflict by providing skills-training and opportunities for networking. Such groups have provided necessary tools for returning women, meeting some of their needs. In Pickering's study, one returning woman who received assistance from a women's organization asserted that, "there were computer exercises and workshops to meet people with the same problems, people who think the same, people who can help others find work...it's very important to meet people and not to fear them." ${ }^{96}$ Consequently, several studies suggest that strategies which seek to incorporate local actors, communities, and NGOs when determining priorities, can positively impact local capacity and networks within civil society. ${ }^{97}$ However, "ordinary people in Bosnia" generally avoid participating in voluntary organizations because they feel that their needs are not being met. ${ }^{98}$ Pickering suggests that this skepticism of voluntary organizations stems partly from the structure of international funding as "Bosnians believe that local voluntary organizations pay more attention to the demands of international donors than to the needs of Bosnians." 99

In his study of international NGOs in Bosnia, Gagnon found several models present in Bosnia, which have experienced varying degrees of success. The most effective NGOs viewed their own work as a two-way process, whereas international agencies assist local NGOs in determining their priorities, while viewing the local officials as equal partners. ${ }^{100}$ Many NGOs in Bosnia, however, have not taken this approach. Instead, they have sought to import ideas to Bosnia without adapting them to the local situation. Inadequate involvement in the community often resulted in the separation of the NGOs from society. McMahon echoes this concern suggesting that the international community has hastily implemented projects in Bosnia that lack domestic support in an attempt to "jump-start" the democratization of the country. ${ }^{101}$

In practice, the mere existence of NGOs on the ground may not reflect the strength of civil society. The emergence of a vibrant, self-sustaining civil society that is

\footnotetext{
${ }^{93}$ Martina Fischer, Confronting the Past, 388.

${ }^{94}$ Paula M. Pickering "Generating Social Capital for Bridging Ethnic Divisions in the Balkans: Case Studies of Two Bosniak Cities," Ethnic and Racial Studies 29, no. 1 (2006): 91.

${ }_{95}$ Pickering Generating Social Capital, 91.

${ }^{96}$ Ibid., 92.

${ }^{97}$ V.P. Gagnon Jr., "International NGOs in Bosnia-Herzegovina: Attempting to Build Civil Society," in The Power and Limits of NGOs, eds. Sarah E. Mendelson and John K. Glenn (New York: Columbia University Press, 2002), 208.

${ }^{98}$ Pickering Generating Social Capital, 90.

${ }^{99}$ Ibid., 91.

${ }^{100}$ V.P. Gagnon Jr., International NGOs in Bosnia-Herzegovina, 223.

${ }^{101}$ McMahon, Rebuilding Bosnia, 580.
} 
prepared to pressure the government cannot rely on the international community for sustainability. In general, international donors struggle with policies and strategies that are inconsistent with the culture of the recipient countries.

In Bosnia, internationally-funded NGOs provide invaluable services to the general public, but there are several practical problems when state-builders rely on the development of civil society to foster a liberal democracy. NGOs that depend on outside funding tend to be more responsive to the concerns of donors, rather than local needs. Furthermore, the invasive international structures in Bosnia have removed the centres of power that were once held by the government. Rather than engaging the government, NGOs feel that they are better served by lobbying the international community. McMahon suggests that the problems associated with civil society development underline the necessity for "domestically appropriate strategies." 102 According to McMahon, a central problem with the approach taken by the international community in Bosnia is that it has left the seemingly insurmountable task of transforming society to the groups with the least amount of resources-NGOs. ${ }^{103}$ Furthermore, despite the rhetoric of civil society development, she suggests that in comparison to investments into other areas (i.e. the economy and state institutions), civil society development has received substantially less financial support. ${ }^{104}$

As Bosnia is dependent on monetary donations from agencies, and organizations, many of the local needs are replaced by the priorities of foreign initiatives. NGOs did not develop their own priorities, but became service providers for specific donor issues. ${ }^{105}$ Consequently, approaches that assume top-down structures rather than working within an equal partnership have the potential to promote strategies that do not reflect local concerns. This, in turn, has limited their support base significantly, contributing to their dependence on foreign funds. While several local NGOs have been started since the end of the war, a great deal of them have since collapsed due to insufficient funding. Further, those that have been able to survive remain extremely vulnerable to the inconsistent donor community. Given the diminishing international support, local NGOs must consider the goals of the international community in order to attract support from the remaining donors. ${ }^{106}$ Further, some reports suggest that, in addition to the inadequate flow of financial support, international donors do not possess enough patience to support peacebuilding over the long-term. Instead, external donors required almost immediate results and avoided committing to extended engagements in one region. ${ }^{107}$ These conditions have created intense competition among the remaining local NGOs, thus reducing their cooperation and overall effectiveness. ${ }^{108}$

\footnotetext{
${ }^{102}$ McMahon, Rebuilding Bosnia, 580.

${ }^{103}$ Ibid., 581.

104 Ibid.

${ }^{105}$ Florian Bieber, "Aid Dependency in Bosnian Politics and Civil Society: Failures and Successes of Postwar Peacebuilding in Bosnia-Herzegovina," Croatian International Relations Review 8, no. 26/27 (2002): 28.

${ }^{106}$ McMahon, Rebuilding Bosnia, 582.

${ }^{107}$ Nenad Vukosavljevic, "Training for Peacebuilding and Conflict Transformation. Experiences of the "Centre for Nonviolent Action" in the Western Balkans," Berghof Research Centre for Constructive Conflict Management available from http://www.berghof-handbook.net (accessed April 5, 2008$), 17$.

${ }^{108}$ McMahon, Rebuilding Bosnia, 582.
} 
Given the potential successes when moving towards a thicker conception of reconciliation (for example, the building of decent relationships, which corresponds with five on Govier's spectrum of reconciliation), it becomes evident that the local, human level must be incorporated as an important component of the peacebuilding process. Clearly, then, genuine consideration and investment into the community should be central to the operational picture. However, there appears to be some resistance to this, or a desire on the donor's part to continue setting internationally-driven agendas in place of the pressing domestic concerns. Indeed, observers suggest that, despite the continued rhetoric, genuine investment into this area has been lacking, especially when compared to the money flowing into other areas of concern. Some estimates suggested that of all the Western aid to the region from the end of the war to 2000, a mere one percent was allocated to civil society development. ${ }^{109}$ Clearly, this was an insignificant amount for an area that has the potential to produce effective results and foster genuine reconciliation at the local level.

\section{Analysis}

On a fundamental level, we can conceive of reconciliation as being the restoring of relationships broken by actual or perceived wrongdoings. Inherent in this notion is the idea of forming relationships between once warring factions to allow for the conception of a new, shared future. Govier envisions reconciliation as existing on a broad spectrum. A thin conception of reconciliation is the ending of violence, the creation of democratic state institutions, and the application of retributive justice (in the case of Bosnia through the ICTY). As evidenced by Bosnia, a thin conception of reconciliation as imposed upon a warring state by the international community, does not seem to be enough to forge lasting relationships between former enemies and create a shared future. Moving closer toward a thicker description of reconciliation must include the building of decent relationships, restorative justice, truth acknowledgement, and forgiveness. This conception of reconciliation also seems to signal a more sustainable approach for the consolidation of peace.

From this perspective, we can begin to evaluate post-Dayton Bosnia. Evidently, the international community was most concerned with the construction of democratic institutions, the application of international law and the conviction of war criminals from Bosnia. The ICTY was viewed by many as a central component in the building of a new Bosnia. This sentiment was most likely driven by the theory of retributive justice. Retributive justice is based upon the notion that punishment is needed to correct the moral imbalance of a society, conveying to aggressors that their behaviour is unacceptable. Further, it is believed that the criminal prosecution of war crimes will individualize guilt, allowing for the emergence of an environment that is conducive to a renewal of relationships between groups. In other words, the conviction of Radovan Karadžić, a former political leader, demonstrated his individual guilt in the killings of Bosniaks, instead of the guilt of the entire Bosnian Serb population. Finally, there is also a hope that trials will reaffirm the commitment to the rule of law in society and possibly set the groundwork for a historical narrative of the atrocities.

\footnotetext{
${ }^{109}$ Kevin F. F. Quigley, "Lofty Goals, Modest Results: Assisting Civil society in Eastern Europe,” in Funding Virtue eds. Martina Ottaway and Thomas Carothers (Washington: Carnegie Endowment for International Peace, 2000), 192.
} 
The ICTY suffered several setbacks. There was very little community outreach, and education about the court was minimal. Given the Court's distance, it was insulated from events on the ground. As a result, many Bosnian Serbs remained highly skeptical of the court and believed that it was unfairly targeting members of their group. The hopes of an irrefutable historical narrative were lost, due to the multiple interpretations according to each group. Drumbl suggests that international criminal law interventions fail to build accountability and restoration, given their top-down approach. This seems to be an inherent flaw in external state-building. As a result, Bosnian society continues to suffer from a dominance of national sentiment and inter-ethnic animosity at the local level. Once mobilized, ethnicity appears to be a durable attribute of identity.

The peacebuilding approach taken by the international community has been a western, liberal response to mass atrocities in a society that continues to be largely shaped by ethnic identities. While retributive justice through the ICTY rulings may be a necessary component in peacebuilding, it is clearly not sufficient for sustainable peace. It appears that a thicker conception of reconciliation is required for sustainable peace in Bosnia. Demands for a truth and reconciliation commission for Bosnia have been present since the end of the war, but are yet to be realized. ${ }^{110}$

Minow suggests that "the very vocabulary of healing and restoration are foreign to the legal language underpinning prosecution." 111 Emotional and psychological healing have not played a dominant role in state-building over the years. This has allowed a culture of denial to persist in Bosnia. As Lederach suggests, "the conceptual paradigm and praxis of peacebuilding must shift significantly away from the traditional framework and activities that make up statist diplomacy." "112 Further, Lederach claims that there needs to be a "movement away from a concern with the resolution of issues and toward a frame of reference that focuses on the restoration and rebuilding of relationships." 113

The state-building tool-kit has largely consisted of state-level approaches. What this and other analyses suggest is that we need to expand the tool-kit to include thicker conceptions of reconciliation that focus on both the societal and individual levels, as well. When genuine investments are made into the local-level, Bosnians are better positioned to promote true forms of reconciliation. Despite this, substantial and consistent support from the international community for local-directed initiatives has been inadequate.

\section{Conclusion}

In conclusion, this paper contributes to the ongoing debate about the incapacity of statecentered mechanisms to appropriately enhance the recreation of social fabric and trust in the aftermath of protracted conflicts. This paper started by introducing the reader to the literature surrounding contemporary warfare and the necessity of a community-centered approach to conflict resolution. We then explored the theoretical dimension of the concept and process of reconciliation. Our exploration of the Bosnian case study

\footnotetext{
${ }^{110}$ Yannick du Pont, "Bosnia and Herzegovina: Trying to Keep the Country Together," in Searching for Peace in Europe and Eurasia ed. Paul van Tongeren, Hans van de Veen, and Juliette Verhoeven (Boulder: Lynne Rienner Publishers, 2002), 243.

${ }_{111}^{11}$ Martha Minow, Between Vengeance and Forgiveness, (Boston: Beacon Press, 1998), 63.

${ }^{112}$ Lederach, Building, 24.

${ }^{113}$ Ibid.
} 
provided a clear illustration of the difficulty encountered in peacebuilding processes. Indeed, while the need to re-build the social fabric of the country is clearly recognized, the efforts carried out by the international community with the creation of the ICTY and the funding of several international agencies, failed to do so. This failure appears to be largely due to the clear disconnect from the individuals and communities scarred by the conflict, as well as the primary/sole focus on institutional state apparatus. The needs of the communities can be better assessed and addressed by local NGOs, but in order for these organizations to be effective, consistent funding needs to be made available by the international community. 


\section{Bibliography}

Akhavan, Payam. "Beyond Impunity: Can International Criminal Justice Prevent Future Atrocities?” American Journal of International Law 95, no. 1 (2001): 7-31.

Assefa, Hizkias. "The Meaning of Reconciliation People Building Peace," European Platform for Conflict Prevention and Transformation, available from http://www.gppac.net/documents/pbp/part1/2_reconc.htm.

Ball, Howard. War Crimes and Justice: A Reference Handbook, Santa Barbara: ABCCLIO, Inc., 2002

Bieber, Florian. "Aid Dependency in Bosnian Politics and Civil Society: Failures and Successes of Post-war Peacebuilding in Bosnia-Herzegovina." Croatian International Relations Review 8, no. 26/27 (2002): 25-30.

Bieber, Florian. "The Challenge of Democracy in Divided Societies: Lessons from Bosnia - Challenges for Kosovo," in Reconstructing Multi-ethnic Societies: The Case of Bosnia-Herzegovina, edited by Dzemal Sokolovic and Florian Bieber, 109-122. Aldershot: Ashgate, 2001.

Bieber, Florian. "Institutionalizing Ethnicity in the Western Balkans. Managing Change in Deeply Divided Societies.” ECMI Working Paper, No. 19 (2004): 1-28.

Bieber, Florian. Post-War Bosnia: Ethnicity, Inequality and Public Sector Governance. New York: Palgrave Macmillan, 2006.

Boyd, Charles "Making Peace with the Guilty." Foreign Affairs 74, no.5 (1995): 22-38.

Busumtwi-Sam, James. "Sustainable Peace and Development in Africa." Studies in Comparative International Development 37, no. 3 (2002): 91-118.

Carothers, Thomas and William Barndt. "Civil Society." Foreign Policy. no, 117, (Winter 1999/2000): 18-24 +26-29.

Cox, Marcus. "Building Democracy from the Outside: The Dayton Agreement in Bosnia and Herzegovina." In Can Democracy Be Designed: The Politics of Institutional Choice in Conflict-torn Societies, edited by Sunil Bastian and Robin Luckham, 253-267. London: Zed Books, 2003.

Drumbl, Mark. Atrocity, Punishment, and International Law. New York: Cambridge University Press, 2007.

du Pont, Yannick. "Bosnia and Herzegovina: Trying to Keep the Country Together." In Searching for Peace in Europe and Eurasia: An Overview of Conflict Prevention 
and Peacebuilding Activities, edited by Paul van Tongeren, Hans van de Veen, and Juliette Verhoeven, 232-247. Boulder: Lynne Rienner Publishers, 2002.

Dwyer, Suzanne. "Reconciliation for Realists." Ethics and International Affairs 13 (1999):81-98.

Faulkner, Frank. "Kindergarten Killers: Morality, Murder \& the Child Soldier Problem." Third World Quarterly 22, no.4 (2001): 491-504.

Fischer, Martina. Confronting the Past and Involving War Veterans for Peace. Activities by the Centre for Nonviolent Action, Sarajevo/Belgrade. In Peacebuilding and Civil Society in Bosnia-Herzegovina. Ten Years after Dayton, edited by Martina Fischer 387-440. Münster: Lit Verlag, 2006.

Fletcher, Laurel E. and Harvey M. Weinstein, "A world unto itself? The application of international justice in the Former Yugoslavia." In My Neighbour, My Enemy: Justice and Community in the Aftermath of Mass Atrocity, edited by Eric Stover and Harvey M. Weinstein, 29-48. Cambridge: Cambridge University Press, 2004.

Fletcher, Laurel E. and Harvey M. Weinsten. "Violence and Social Repair: Rethinking the Contribution of Justice to Reconciliation" Human Rights Quarterly 24, no.3 (2002): 573-639.

Gagnon Jr., V.P. "International NGOs in Bosnia-Herzegovina: Attempting to Build Civil Society." In The Power and Limits of NGOs, edited by Sarah E. Mendelson and John K. Glenn, 207-231. New York: Columbia University Press, 2002.

Govier, Trudy. Taking Wrongs Seriously: Acknowledgement, Reconciliation, and the Politics of Sustainable Peace, (Amherst: Humanity Books, 2006).

Guzina, Dejan. "Dilemmas of Nation-building and Citizenship in Dayton Bosnia," National Identities 9, no. 3 (2007): 217-234.

Guzina, Dejan. "How Multiethnic is Democracy in the Balkans: The Case of Bosnia" Paper presented at the annual meeting of the International Studies Association, Hilton Hawaiian Village, Honolulu, Hawaii, March 5, 2005, available from http://www.allacademic.com/meta/p70760_index.html (accessed April 1, 2008).

Jeong, Ho-wong. Peacebuilding in post conflict societies: strategy and processes. Boulder: Lynne Rienner Publisher, 2005.

Hesse, Carla and Robert Post, "Introduction," in Human Rights in Political Transitions: Gettysburg to Bosnia, edited by Carla Hesse and Robert Post, 13-38. New York: Zone Books, 1999. 
Kerr, Rachel. "The Road from Dayton to Brussels? The International Criminal Tribunal for the Former Yugoslavia and the Politics of War Crimes in Bosnia," European Security 14, no. 3 (2005): 319-337.

Knaus, Gerald and Marcus Cox, "Bosnia and Herzegovina: Europeanisation by decree?" in The western Balkans moving on (Chaloit Papers 70), edited by Judy Batt 5568. Paris: Institute for Security Studies, 2004.

Lederach, Jean Paul. Building Peace: Sustainable Reconciliation in Divided Societies. Washington: United States Institute of Peace Press, 1997.

Lijphart, Arend. "Constitutional Design for Divided Societies." Journal of Democracy 15, no. 2, (2004): 96-110.

Loza, Tihomir. "Shades of Yugoslavia." Tol.cz, September 25, 2007, http://www.tol.cz /loo $\mathrm{k} / \mathrm{TOL} /$ article.tpl?IdLanguage $=1 \&$ IdPublication $=\quad 4 \& N r$ Article $=19016 \&$ NrIssue $=237 \& \mathrm{~N}$ rSecti on $=2$ (accessed 27 November 2007).

McMahon, Patrice. "Rebuilding Bosnia: A Model to Emulate or to Avoid?" Political Science Quarterly 119, no. 4, ( 2004/2005): 569-593.

Meernik, James. "Justice and Peace? How the International Criminal Tribunal Affects Societal Peace in Bosnia," Journal of Peace Research 42, no. 3 (2005): 271-289.

Mendelson, Sarah E. And John K. Glenn. "Introduction: Transnational Networks and NGOs in Postcommunist Societies." In The Power and Limits of NGOs : a critical look at building democracy in Eastern Europe and Eurasia, edited by Sarah E. Mendelson and John K. Glenn, 1-28. New York: Columbia University Press, 2002.

Minow, Martha. Between Vengeance and Forgiveness. Boston: Beacon Press, 1998.

Neier, Aryeh. War Crimes: Brutality, Genocide, Terror, and the Struggle for Justice. New York: Times Books, 1998.

Pajic, Zoran. "Statehood at a Crossroads." Tol.cz, February 10, 2006, http:/www.tol.cz/loo k/TOL/ article.tpl?IdLanguage=1\&IdPublication=4\&Nr Issue $=153 \& N r S e c t i o n=2 \& N r A r t \quad$ icle $=15812 \&$ search $=$ search $\&$ SearchKeyw ords $=$ Pajic $\&$ SearchMode $=$ on $\&$ SearchLevel $=0$ (accessed December 1,2007$)$.

Paris, Roland. At War's End: Building Peace after Civil Conflict. Cambridge: Cambridge University Press, 2004.

Pickering, Paula M. "Generating Social Capital for Bridging Ethnic Divisions in the Balkans: Case Studies of Two Bosniak Cities." Ethnic and Racial Studies 29, no. 1 (2006): 79-103. 
Quigley, Kevin F. F. "Lofty Goals, Modest Result: Assisting Civil Society in Eastern Europe." In Funding Virtue edited by Martina Ottaway and Thomas Carothers, 191-216. Washington: Carnegie Endowment for International Peace, 2000.

Rigby, Andrew. Justice and Reconciliation: After the Violence. Boulder: Lynne Rienner Publishers, 2001.

Rupesinghe, Karl. Civil wars and civil peace: An introduction to conflict resolution. London: Pluto Press, 1998.

Saunders, Harold. A Public Peace Process: Sustained Dialogue to Transform Racial and Ethnic Conflict. New York: Palgrave, 1999.

Schneckener, Ulrich. "Making Power-sharing Work: Lessons from Successes and Failures in Ethnic Conflict Regulation." Journal of Peace Research 39, no. 2, (2002): 203-228.

Sejfija, Ismet. "From the 'Civil Sector' to Civil Society?" In Peacebuilding and Civil Society in Bosnia-Herzegovina: Ten Years after Dayton ed. Martina Fischer, 125140, Munster: Lit-Verlag, 2006.

Snyder, Jack and Leslie Vinjamuri, "Trials and Errors: Principle and Pragmatism in Strategies of International Justice," International Security 28, no. 3 (2003/4): 544.

Taylor, Charles. "Civil Society in the Western Tradition," in The Notion of Tolerance and Human Rights edited by Ethel Groffier and Michel Paradis, 117-136. Ottawa: Carleton University Press, 1991.

Teitel, Ruti. "Bringing the Messiah Through the Law." In Human Rights in Political Transitions: Gettysburg to Bosnia edited by Carla Hesse \& Robert Post, 177-194. New York: Zone Books, 1999.

Vukosavljevic, Nenad. "Training for Peacebuilding and Conflict Transformation. Experiences of the "Centre for Nonviolent Action" in the Western Balkans." Berghof Research Centre for Constructive Conflict Management available from http://www.berghof-handbook.net (accessed April 5, 2008). 